\title{
Optimization and Comparison of Direct and Indirect Supercritical Carbon Dioxide Power Plant Cycles for Nuclear Applications
}

\section{IMECE 2011}

\author{
Edwin A. Harvego \\ Michael G. McKellar
}

The INL is a

U.S. Department of Energy

National Laboratory

operated by

Battelle Energy Alliance

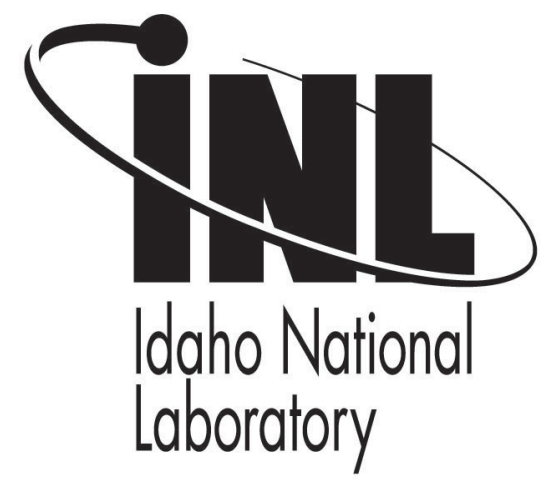

This is a preprint of a paper intended for publication in a journal or proceedings. Since changes may be made before publication, this preprint should not be cited or reproduced without permission of the author. This document was prepared as an account of work sponsored by an agency of the United States Government. Neither the United States Government nor any agency thereof, or any of their employees, makes any warranty, expressed or implied, or assumes any legal liability or responsibility for any third party's use, or the results of such use, of any information, apparatus, product or process disclosed in this report, or represents that its use by such third party would not infringe privately owned rights. The views expressed in this paper are not necessarily those of the United States Government or the sponsoring agency. 


\title{
OPTIMIZATION AND COMPARISON OF DIRECT AND INDIRECT SUPERCRITICAL CARBON DIOXIDE POWER PLANT CYCLES FOR NUCLEAR APPLICATIONS
}

\author{
Edwin A. Harvego and Michael G. McKellar \\ Idaho National Laboratory \\ Idaho Falls, ID 83415, USA
}

\begin{abstract}
Results of analyses performed using the UniSim process analyses software to evaluate the performance of both a direct and indirect supercritical $\mathrm{CO}_{2}$ Brayton power plant cycle with recompression at different reactor outlet temperatures are presented. The direct supercritical $\mathrm{CO}_{2}$ power plant cycle transferred heat directly from a $600 \mathrm{MW}_{\mathrm{t}}$ reactor to the supercritical $\mathrm{CO}_{2}$ working fluid supplied to the turbine generator at approximately $20 \mathrm{MPa}$. The indirect supercritical $\mathrm{CO}_{2}$ cycle assumed a helium-cooled Very High Temperature Reactor (VHTR), operating at a primary system pressure of approximately 7.0 MPa, delivered heat through an intermediate heat exchanger to the secondary indirect supercritical $\mathrm{CO}_{2}$ recompression Brayton cycle, again operating at a pressure of about $20 \mathrm{MPa}$. For both the direct and indirect power plant cycles, sensitivity calculations were performed for reactor outlet temperature between $550^{\circ} \mathrm{C}$ and $850^{\circ} \mathrm{C}$. The UniSim models used realistic component parameters and operating conditions to model the complete reactor and power conversion systems. $\mathrm{CO}_{2}$ properties were evaluated, and the operating ranges of the cycles were adjusted to take advantage of the rapidly changing properties of $\mathrm{CO}_{2}$ near the critical point. The results of the analyses showed that, for the direct supercritical $\mathrm{CO}_{2}$ power plant cycle, thermal efficiencies in the range of approximately 40 to $50 \%$ can be achieved over the reactor coolant outlet temperature range of $550^{\circ} \mathrm{C}$ to $850^{\circ} \mathrm{C}$. For the indirect supercritical $\mathrm{CO}_{2}$ power plant cycle, thermal efficiencies were approximately $11-13 \%$ lower than those obtained for the direct cycle over the same reactor outlet temperature range.
\end{abstract}

\section{NOMENCLATURE}

$\mathrm{CO}_{2} \quad$ Carbon Dioxide

IHX Intermediate Heat Exchanger

NGNP Next Generation Nuclear Plant
$\dot{W}_{\text {Circulator }}$
Helium circulator power (MW)
$\dot{W}_{\text {Compressors }}$
Total compressor power (MW)
$\dot{W}_{\text {Turbine }}$
Turbine power (MW)
$\dot{Q}_{\text {Re actor }}$
Reactor heat (MW)
VHTR
Very High Temperature Reactor
$\eta_{p c s}$
Power conversion cycle thermal efficiency

\section{INTRODUCTION}

This study provides an evaluation and comparison of the performance of direct and indirect supercritical $\mathrm{CO}_{2}$ power plant cycles operating in a reactor outlet temperature range between $550^{\circ} \mathrm{C}$ and $850^{\circ} \mathrm{C}$. The power plant cycle selected for this study is referred to as a supercritical $\mathrm{CO}_{2}$ closed Brayton cycle (also known as the Joule cycle) with recompression. This power plant cycle was originally described by Dostal in his ScD Thesis/Topical Report [1], and subsequently referenced in a variety of other publications [29].

The Next Generation Nuclear Plant (NGNP) is a proposed full scale facility to be used to demonstrate the commercial potential of a high temperature gas-cooled nuclear reactor for electricity and process heat applications. The current reference design for the NGNP is a helium-cooled Very High Temperature Reactor (VHTR) operating with a $750^{\circ} \mathrm{C}$ reactor coolant outlet temperature. For NGNP applications, the supercritical $\mathrm{CO}_{2}$ recompression Brayton cycle would be operated as an indirect power conversion cycle, in which the helium-cooled VHTR, operating at a primary system pressure of approximately 7.0 MPa, delivers heat through an intermediate heat exchanger to the secondary indirect supercritical $\mathrm{CO}_{2}$ recompression Brayton cycle operating at a pressure of about $20 \mathrm{MPa}$. However, the direct supercritical 
$\mathrm{CO}_{2}$ power plant cycle, in which heat from the $600 \mathrm{MW}_{\mathrm{t}}$ reactor is transferred directly to the supercritical $\mathrm{CO}_{2}$ working fluid supplied to the turbine generator at approximately 20 $\mathrm{MPa}$, was first evaluated to allow optimization of the power cycle loop without the added complication of connecting to a primary loop [10]. The indirect power plant cycle was then evaluated so that a comparison of the differences in operating characteristics and performance of the two cycles could be made.

The supercritical $\mathrm{CO}_{2}$ Brayton power plant cycle with recompression was selected for evaluation because of its relatively high power conversion efficiencies for turbine inlet temperatures between $550^{\circ} \mathrm{C}$ and $750^{\circ} \mathrm{C}$ compared to the efficiencies that can be achieved using a closed-loop recuperated helium Brayton cycle. The supercritical $\mathrm{CO}_{2}$ cycle achieves these high efficiencies by taking advantage of the rapidly changing properties of $\mathrm{CO}_{2}$ at temperatures and pressures slightly above the critical point $(7.38 \mathrm{MPa}$ and $31.1^{\circ} \mathrm{C}$ ). The following two sections describe the UniSim model and analysis results for the direct and indirect supercritical Brayton power plant cycles with recompression. This is followed by a comparison of performance parameters for the two cycles and the conclusions of the study.

\section{DIRECT SUPERCRITICAL $\mathrm{CO}_{2}$ RECOMPRESSION BRAYTON POWER PLANT CYCLE}

The UniSim process analysis software was used in the evaluation of the direct supercritical $\mathrm{CO}_{2}$ recompression Brayton power plant cycle. The reference design for the direct power conversion cycle assumed a reactor outlet temperature of $750^{\circ} \mathrm{C}$ and a reactor power of $600 \mathrm{MW}_{\mathrm{t}}$. The high pressure portion of the cycle was limited to approximately $20 \mathrm{MPa}$ to avoid the potential large irreversibility in the power conversion system high temperature recuperator, which is the result of a pinch point problem described by Dostal, et. al. [1] and others. Realistic component operating conditions and design parameters were selected to be consistent with those assumed for the NGNP Project. In particular, the compressors and turbine were assumed to have an adiabatic efficiency of $90 \%$, and the minimum approach temperature for all shell and tube heat exchangers in the power conversion system was conservatively assumed to be $20^{\circ} \mathrm{C}$.

Figure 1 shows the UniSim model of the supercritical $\mathrm{CO}_{2}$ recompression Brayton power plant cycle. The calculated stream conditions (flow rates, temperatures and pressures) at different points in the system are indicated on the flow sheet.

In the reference design, the supercritical $\mathrm{CO}_{2}$ coolant

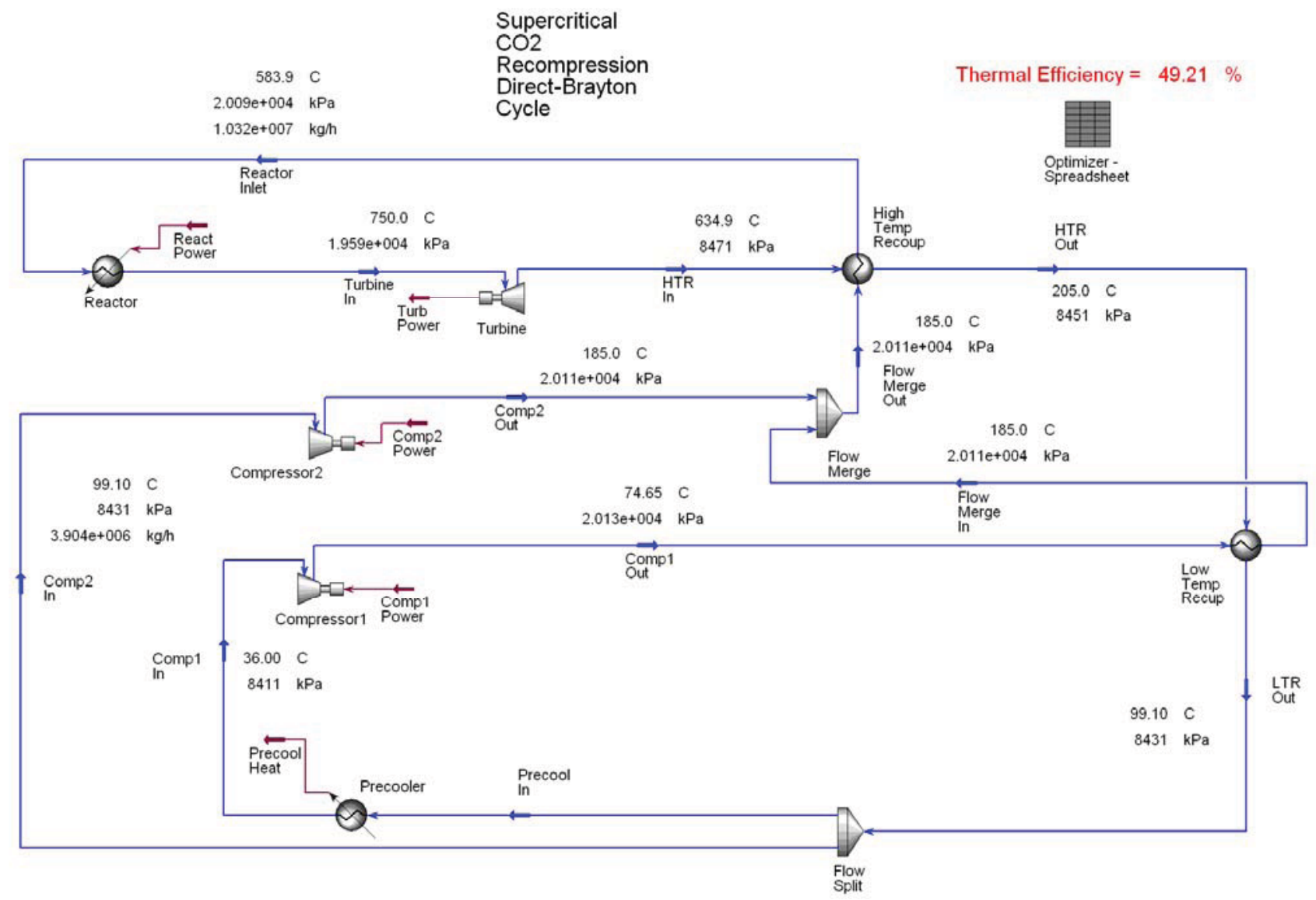

Figure 1. Unisim model of supercritical $\mathrm{CO} 2$ direct Brayton cycle with recompression. 
enters the reactor (upper left corner of Figure 1) at approximately $584^{\circ} \mathrm{C}$ and $20 \mathrm{MPa}$. After being heated in the reactor to $750^{\circ} \mathrm{C}$, the coolant is expanded through the turbine to produce electric power. The coolant, at a lower temperature and pressure then passes through high-temperature and lowtemperature recuperators, where it is further cooled. The coolant flow is then split into two streams (bottom of Figure 1). One stream passes through a precooler that provides additional cooling to the working fluid before it enters Compressor 1. Compressor 1 provides the driving force to circulate the fluid back through the two recuperators where heat is recovered before the working fluid is returned to the reactor inlet to complete the cycle. The second split stream at the bottom of Figure 1 passes directly to Compressor 2 (the recompressor) without any additional cooling, where it is compressed and joined with the first split stream before passing through the high temperature recuperator and returning to the reactor inlet to complete the cycle.

The calculated power conversion cycle thermal efficiency $\left(\eta_{\text {pcs }}\right)$ for the conditions shown in Figure 1 is $49.2 \%$, where $\eta_{\text {pcs }}$ is defined as:

$$
\eta_{p c s}=\left(\dot{W}_{\text {Turbine }}-\dot{W}_{\text {Compressors }}\right) / \dot{Q}_{\operatorname{Re} \text { actor }}
$$

and,

$\dot{W}_{\text {Turbine }}=$ Power of the primary side turbine

$\dot{W}_{\text {Compressors }}=$ Power of high and low pressure compressors

$\dot{Q}_{\text {Reactor }}=$ Reactor heat.

Table 1 summarizes the power cycle parameters and operating conditions selected for the reference direct power cycle design. For a reactor outlet temperature of $750^{\circ} \mathrm{C}$ and a coolant flow rate of $2867 \mathrm{~kg} / \mathrm{s}$, the optimized pressure ratio (ratio of maximum to minimum pressures in the power cycle) giving the highest power cycle thermal efficiency was found to be 2.3. The calculated recompression fraction, which is defined to be the ratio of coolant flow to Compressor 2 (the flow bypassing the precooler) divided by the total coolant

Table 1. Reference design parameters for direct cycle.

\begin{tabular}{|l|l|}
\hline Reactor Heat, $\mathrm{MW}_{\mathrm{t}}$ & 600 \\
\hline Reactor inlet pressure, $\mathrm{MPa}$ & 20 \\
\hline Reactor outlet temperature, ${ }^{\circ} \mathrm{C}$ & 750 \\
\hline Coolant flow rate, $\mathrm{kg} / \mathrm{s}$ & 2867 \\
\hline Pressure ratio & 2.3 \\
\hline Recompression fraction & 0.435 \\
\hline Heat rejection rate (waste heat), MW & 305 \\
\hline Compressor/turbine power ratio & 0.268 \\
\hline $\begin{array}{l}\text { Minimum approach temperature (all } \\
\text { heat exchangers), }{ }^{\circ} \mathrm{C}\end{array}$ & 20 \\
\hline $\begin{array}{l}\text { Tube and shell side pressure drop (all } \\
\text { heat exchangers), } \mathrm{kPa}\end{array}$ & 20 \\
\hline
\end{tabular}

mass flow) is 0.435 . With only a fraction of the total coolant flow rejecting its heat to the precooler at a sink temperature of $36^{\circ} \mathrm{C}$, the power cycle heat rejection rate (waste heat) is 305 MW. This compares to a waste heat rejection rate of approximately $358 \mathrm{MW}$ for an equivalent direct helium Brayton power plant cycle powered by a $600 \mathrm{MW}_{\mathrm{t}}$ reactor at a reactor outlet temperature of $750^{\circ} \mathrm{C}$ [11]. The waste heat rejection rate for the supercritical $\mathrm{CO}_{2}$ recompression Brayton cycle is, therefore, approximately $15 \%$ less than that of the equivalent recuperated helium Brayton cycle, contributing to the overall higher thermal efficiency of the supercritical $\mathrm{CO}_{2}$ recompression Brayton power plant cycle.

Finally, a comparison of the ratio of the net power of the two compressors to the output power of the turbine $\left(8^{\text {th }}\right.$ row in Table 1) shows a compressor-to-turbine power ratio of 0.268 . This compares with a typical compressor-to-turbine power ratio of approximately 0.45 for a recuperated helium Brayton cycle, and demonstrates the reduced compression work that can be achieved by taking advantage of the higher density of supercritical $\mathrm{CO}_{2}$ near the critical point.

\section{INDIRECT SUPERCRITICAL $\mathrm{CO}_{2}$ RECOMPRESSION BRAYTON POWER PLANT CYCLE}

The UniSim model for the reference Indirect Supercritical $\mathrm{CO}_{2}$ Brayton power plant cycle with recompression is shown in Figure 2. The indirect power cycle is identical to the direct cycle shown in Figure 1, but the supercritical $\mathrm{CO}_{2}$ reactor power source has been replaced with an intermediate heat exchanger (IHX) to transfer heat from the reactor primary loop to the indirect supercritical $\mathrm{CO}_{2}$ power conversion cycle. The primary loop shown in the upper left hand corner of Figure 2 consists of a helium-cooled VHTR power source. Heat from the reactor is transferred to the helium coolant and then to the indirect supercritical $\mathrm{CO}_{2}$ power conversion cycle through the IHX. The cooler helium is then delivered to the helium circulator (K-100) which returns the coolant to the reactor inlet at the desired inlet pressure. For the reference design case, the reactor outlet temperature and pressure were assumed to be $750^{\circ} \mathrm{C}$ and $7.0 \mathrm{MPa}$, respectively. To provide the same power to the indirect power cycle, as was assumed for the direct power cycle, the VHTR power was reduced to $515 \mathrm{MW}_{\mathrm{t}}$ to account for the $85 \mathrm{MW}$ heat of compression added to the primary loop by the helium circulator (K-100). The resulting total heat transferred through the IHX to the indirect supercritical $\mathrm{CO}_{2}$ power cycle was $600 \mathrm{MW}$.

The helium coolant mass flow rate was $500 \mathrm{~kg} / \mathrm{s}$. The pressure drop through the reactor was assumed to be $500 \mathrm{kPa}$ and the pressure drop on both the primary and secondary sides of the IHX were assumed to be $50 \mathrm{kPa}$. The helium temperature and pressure at the reactor inlet were $552^{\circ} \mathrm{C}$ and 7.5 $\mathrm{MPa}$, respectively. This reactor inlet temperature is higher than that specified for NGNP, but is unavoidable because of the thermodynamic characteristics of the system. The only way to effectively reduce the reactor inlet temperature would be to incorporate a heat exchanger between the helium circulator (K-100) and the reactor inlet and utilize the rejected 
heat in a combined power cycle or for some other purpose. However, this was not part of the current study.

For the indirect power cycle in Figure 2, heat exchanger pressure drops and minimum approach temperatures were the same as assumed in the direct power conversion cycle of Figure 1. However, to achieve solution convergence, the minimum approach temperature for the low temperature recuperator (Low Temp Recup) in Figure 2 was reduced to approximately $8^{\circ} \mathrm{C}$.

For the reference reactor outlet temperature of $750^{\circ} \mathrm{C}$, a turbine inlet temperature of $650^{\circ} \mathrm{C}$ was assumed. This resulted in a minimum approach temperature of $37.8^{\circ} \mathrm{C}$ for the IHX, which was felt to be reasonable. For these conditions, the calculated power conversion cycle thermal efficiency $\left(\eta_{\mathrm{pcs}}\right)$ for the indirect supercritical $\mathrm{CO}_{2}$ Brayton power cycle with recompression (shown in Figure 2) is $38.8 \%$, where in this case $\eta_{\mathrm{pcs}}$ is defined as:

$\eta_{p c s}=\left(\dot{W}_{\text {Turbine }}-\dot{W}_{\text {Compressors }}-\dot{W}_{\text {Circulator }}\right) / \dot{Q}_{\text {Re actor }}$

and,

$\dot{W}_{\text {Turbine }}=$ Power of the indirect power cycle turbine

$\dot{W}_{\text {Compressors }}=$ Power of high and low pressure compressors on the secondary side of the IHX

$\dot{W}_{\text {Circulator }}=$ Power of the primary helium circulator

$\dot{Q}_{\text {Re actor }}=$ Reactor heat.

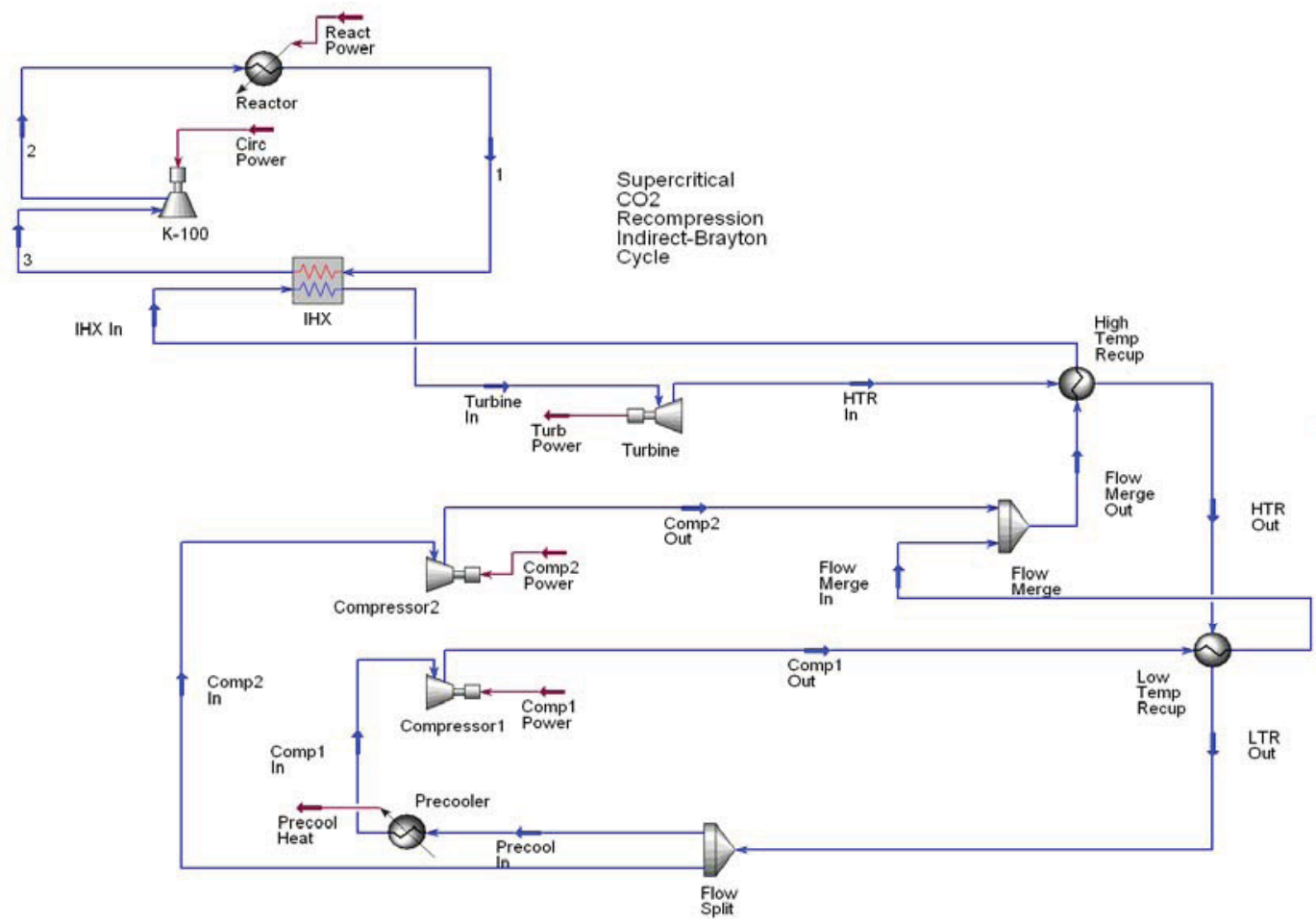

Figure 2. UniSim model of indirect Brayton cycle with recompression.
Table 2 summarizes the primary side and secondary indirect power cycle parameters for the reference design shown in Figure 2. Overall, the indirect power cycle parameters were very similar to those for the direct power cycle. However, the temperature drop across the intermediate heat exchanger (IHX) and the additional power requirement for the primary helium circulator $(\mathrm{K}-100)$, resulted in a drop in overall power plant cycle efficiency from $49.2 \%$ for the direct cycle shown in Figure 1 to 38.8\% shown in Figure 2.

\section{COMPARISON OF DIRECT AND INDIRECT SUPERCRITICAL $\mathrm{CO}_{2}$ RECOMPRESSION BRAYTON POWER PLANT CYCLES}

Several sensitivity studies were performed to compare the performance of the direct and indirect supercritical $\mathrm{CO}_{2}$ Brayton power plant cycles with recompression. The effect of reactor outlet temperature, power cycle pressure ratio (ratio of power cycle maximum to minimum pressures), and recompression fraction on system performance were examined.

Figure 3 compares the direct and indirect power cycle efficiencies for reactor coolant outlet temperatures ranging from $550^{\circ} \mathrm{C}$ to $850^{\circ} \mathrm{C}$. Throughout this range of temperatures, the indirect power plant cycle exhibited lower power cycle efficiencies of between approximately $11 \%$ and $13 \%$ when compared to the direct power plant cycle. These lower efficiencies were a result of the additional power consumed by the primary loop circulator $(\mathrm{K}-100)$ required to circulate the helium coolant used to remove heat from the reactor core and transfer this heat through the IHX to the secondary 
Table 2. Reference design parameters for indirect cycle.

\begin{tabular}{|l|l|}
\hline Primary Loop & \\
\hline Reactor Power, $\mathrm{MW}_{\mathrm{t}}$ & 515 \\
\hline Helium circulator Power, MPa & 85 \\
\hline $\begin{array}{l}\text { Reactor coolant inlet pressure, } \\
\mathrm{MPa}\end{array}$ & 7.5 \\
\hline $\begin{array}{l}\text { Reactor coolant inlet } \\
\text { temperature, }{ }^{\circ} \mathrm{C}\end{array}$ & 552 \\
\hline $\begin{array}{l}\text { Reactor coolant outlet } \\
\text { temperature, }{ }^{\circ} \mathrm{C}\end{array}$ & 750 \\
\hline Coolant flow rate, kg/s approach & 37.8 \\
\hline $\begin{array}{l}\text { IHX minimum } \\
\text { temperature, }{ }^{\circ} \mathrm{C}\end{array}$ & 500 \\
\hline $\begin{array}{l}\text { IHX primary side pressure drop, } \\
\mathrm{kPa}\end{array}$ & 50 \\
\hline Secondary Power Cycle Loop & 2867 \\
\hline Coolant flow rate, kg/s & 20 \\
\hline Turbine inlet pressure, MPa & 650 \\
\hline Turbine inlet temperature, ${ }^{\circ} \mathrm{C}$ & 2.55 \\
\hline Pressure ratio & 0.225 \\
\hline Recompression fraction & 315 \\
\hline $\begin{array}{l}\text { Heat rejection rate (waste heat), } \\
\text { MW }\end{array}$ & 0.281 \\
\hline Compressor/turbine power ratio & 0 \\
\hline $\begin{array}{l}\text { IHX secondary side pressure } \\
\text { drop, kPa }\end{array}$ & 50 \\
\hline $\begin{array}{l}\text { High Temperature Recuperator } \\
\text { minimum approach temperature, } \\
{ }^{\circ} \mathrm{C}\end{array}$ & 20 \\
\hline $\begin{array}{l}\text { Low Temperature Recuperator } \\
\text { minimum approach temperature, } \\
{ }^{\circ} \mathrm{C}\end{array}$ & 8 \\
\hline $\begin{array}{l}\text { Tube and shell side pressure } \\
\text { drops (precooler and recuperative } \\
\text { exchangers), kPa }\end{array}$ & 20 \\
\hline
\end{tabular}

supercritical $\mathrm{CO}_{2}$ power cycle loop. The temperature drop across the IHX also contributed to a lower efficiency for the indirect power cycle because of the lower resultant inlet temperature to the turbine generator.

The power plant cycle efficiencies plotted as a function of optimized power cycle pressure ratio (ratio of maximum to minimum pressures in the power cycle) for the direct and indirect power plant cycles are shown in Figure 4. Both the direct and indirect power plant cycles show similar trends of decreasing power cycle efficiency with increasing power cycle pressure ratio. The lower overall efficiency of the indirect power cycle compared to the direct power cycle is again attributable to the additional power consumed by the primary loop helium circulator and the temperature drop across the IHX, which results in a lower inlet temperature to the turbine generator.

This dependency of the overall power cycle efficiency on the coolant inlet temperature to the turbine generator can be seen in Figure 5, where the power cycle efficiency is plotted as

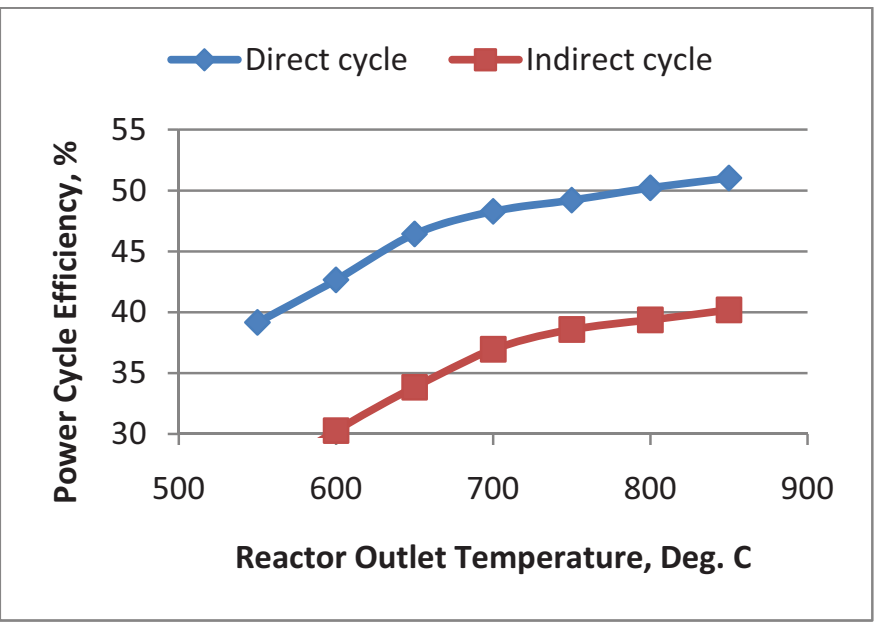

Figure 3. Comparison of direct and indirect power cycle efficiencies versus reactor outlet temperature.

a function of turbine inlet temperature for both the direct and indirect power cycles.

Finally, the power cycle efficiency versus recompression fraction is shown in Figure 6 for both the direct and indirect cycles. Generally, the trends are similar, but appear to be somewhat influenced by differences in fluid conditions on the low pressure side of the power cycle, which as discussed earlier are changing rapidly near the $\mathrm{CO}_{2}$ critical point.

\section{CONCLUSIONS}

Analyses were performed to compare the performance of direct and indirect supercritical $\mathrm{CO}_{2}$ Brayton power plant cycles with recompression. The analyses showed that for the direct supercritical $\mathrm{CO}_{2}$ cycle, relatively high power cycle thermal efficiencies can be achieved for turbine inlet

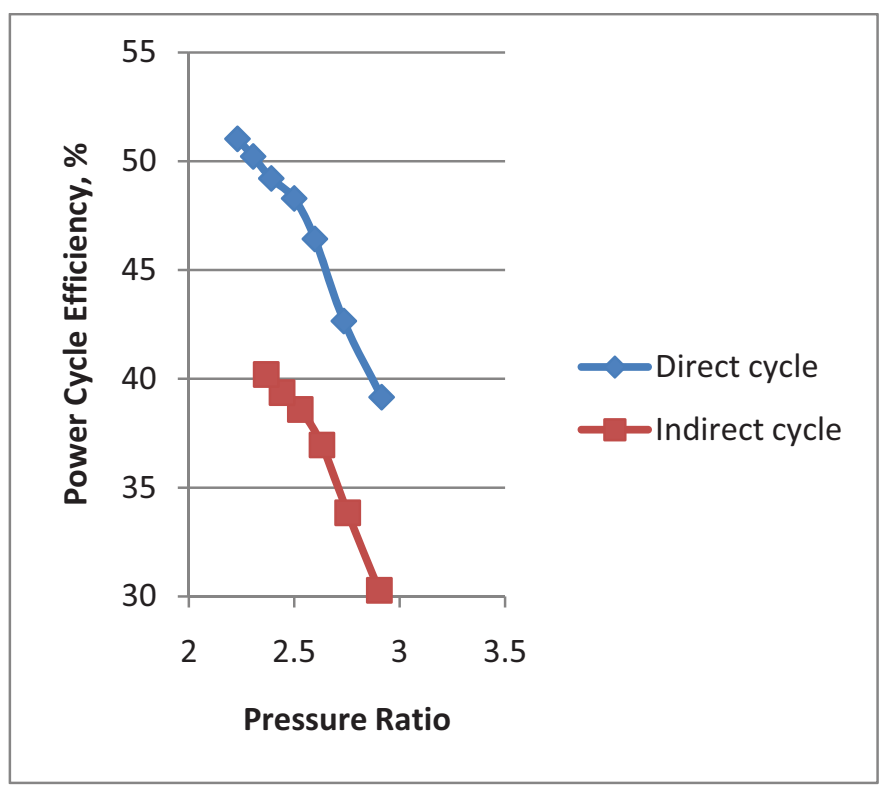

Figure 4. Comparison of direct and indirect power cycle efficiencies versus power cycle pressure ratio. 


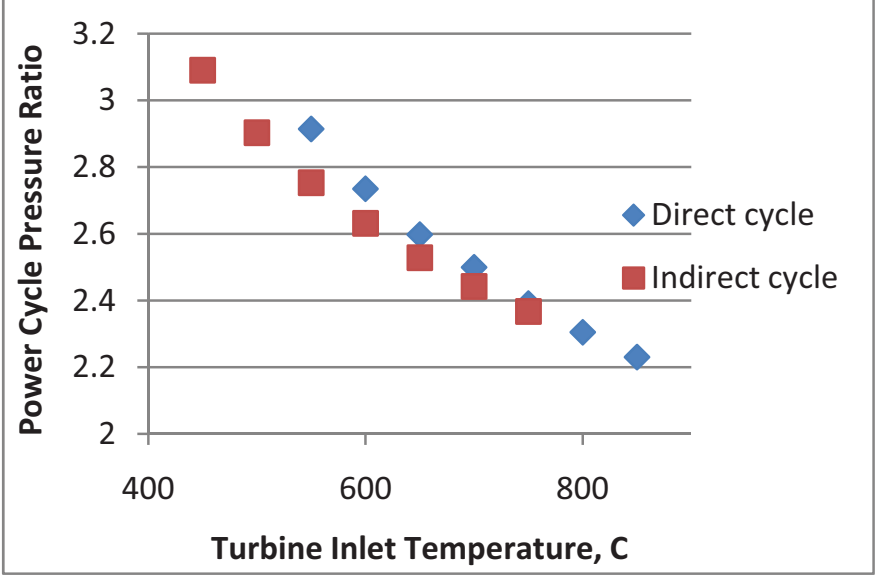

Figure 5. Direct and indirect power cycle pressure ratio versus turbine inlet temperature.

temperatures in the range of $550^{\circ} \mathrm{C}$ to $850^{\circ} \mathrm{C}$. For a $600 \mathrm{MW}_{\mathrm{t}}$ supercritical $\mathrm{CO}_{2}$ cooled reactor operating at a reference coolant outlet temperature of $750^{\circ} \mathrm{C}$, maximum system pressure of $20 \mathrm{MPa}$, and a coolant flow rate of $2867 \mathrm{~kg} / \mathrm{s}$, a maximum power cycle thermal efficiency of $49.2 \%$ was achieved. The maximum possible power cycle efficiency, assuming a Carnot cycle using an ideal gas as the working fluid and heat source and heat sink temperatures of $750^{\circ} \mathrm{C}$ and $20^{\circ} \mathrm{C}$, respectively, is $71.4 \%$. Therefore, the direct supercritical $\mathrm{CO}_{2}$ power plant cycle operating at a reactor outlet temperature of $750^{\circ} \mathrm{C}$ achieves about $69 \%$ of the maximum possible Carnot cycle efficiency, which is close to the maximum efficiency that can be expected for an actual power plant cycle assuming realistic component operating

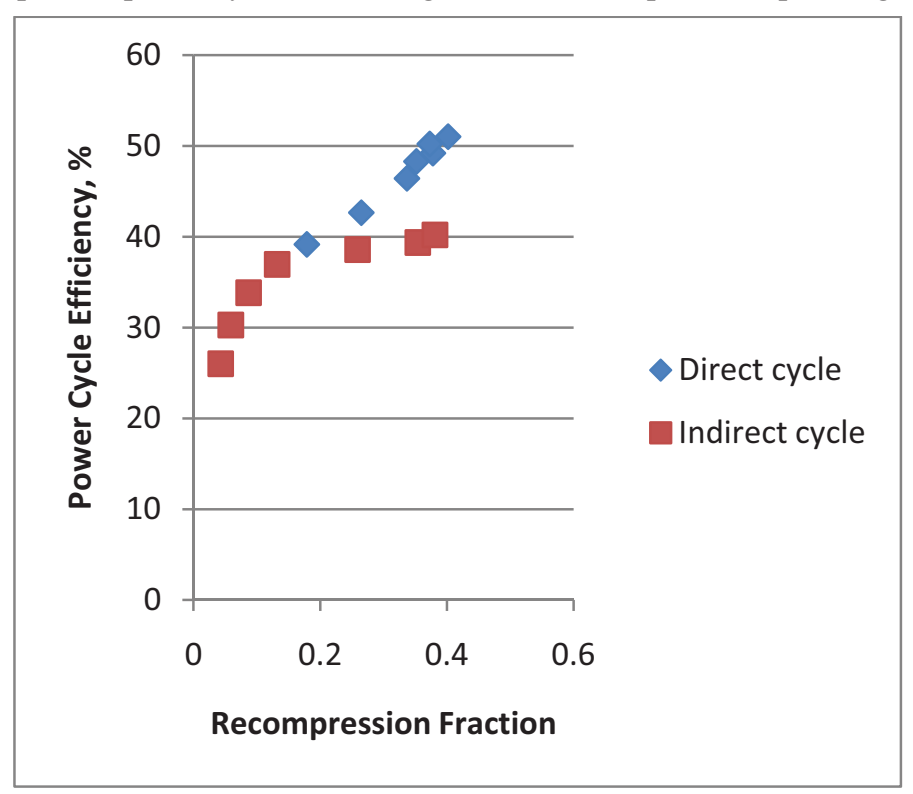

Figure 6. Comparison of direct and indirect power cycle efficiency versus recompression fraction. conditions and design parameters [12].

The relatively high power cycle thermal efficiency obtained for the supercritical $\mathrm{CO}_{2}$ recompression Brayton cycle at temperatures in the range of $550^{\circ} \mathrm{C}$ to $850^{\circ} \mathrm{C}$, combined with the simplicity and compactness of the power conversion system design make this an attractive option for high temperature reactor applications. However, for NGNP applications, an indirect power plant cycle is of interest because of the improved safety features (isolation of the primary system from the high pressure $\mathrm{CO}_{2}$ power cycle working fluid) and the potential to use other high-temperature reactor concepts (helium-cooled gas reactors or molten salted cooled reactors).

Therefore, analyses of an indirect supercritical $\mathrm{CO}_{2}$ Brayton power cycle with recompression, driven by a VHTR with heat transferred from the primary helium coolant loop through an IHX to the secondary supercritical $\mathrm{CO}_{2}$ working fluid, were also performed and compared with the direct cycle results. The analyses of the indirect Brayton power cycle with recompression produced power cycle thermal efficiencies $11 \%$ to $13 \%$ below those obtained for the direct power cycle over the reactor coolant outlet temperature range of $550^{\circ} \mathrm{C}$ to $850^{\circ} \mathrm{C}$. At an NGNP reference reactor coolant outlet temperature of $750^{\circ} \mathrm{C}$, the indirect power plant cycle thermal efficiency was $38.8 \%$, compared to $49.2 \%$ for the direct power plant cycle.

\section{ACKNOWLEDGMENTS}

This work was supported by the U.S. Department of Energy, Office of Nuclear Energy, Next Generation Nuclear Plant project.

\section{COPYRIGHT STATEMENT}

This manuscript has been authored by Battelle Energy Alliance, LLC under Contract No. DE-AC07-05ID14517 with the U.S. Department of Energy. The United States Government retains and the publisher, by accepting the article for publication, acknowledges that the United States Government retains a nonexclusive, paid-up, irrevocable, world-wide license to publish or reproduce the published form of this manuscript, or allow others to do so, for United States Government purposes.

\section{REFERENCES}

1. Dostal, V., Driscoll, M. J., Hejzlar, P., “A Supercritical Carbon Dioxide Cycle for Next Generation Nuclear Reactors, MIT-ANP-TR-100200, 2004.

2. Dostal, V., Hejzlar, P. and Driscoll, M., "HighPerformance Supercritical Carbon Dioxide Cycle for Next-Generation Nuclear Reactors", Nuclear Technology, Vol.154, 265, 2006.

3. Dostal, V., Hejzlar, P. and Driscoll, M., "The Supercritical Carbon Dioxide Power Cycle: Comparison with Other Advanced Power Cycles", Nuclear Technology, Vol. 154, 283, 2006.

4. Sarkar, J. and Bhattacharyya, S., "Optimization of 
recompression $\mathrm{S}-\mathrm{CO}_{2}$ power cycle with reheating", Energy Conversion and Management, Vol. 50, Issue 8, 1939-1945, August 2009.

5. Sarkar, J., "Second law analysis of supercritical $\mathrm{CO}_{2}$ recompression Brayton cycle", Energy, Vol.34, Issue 9, 1172-1178, September 2009.

6. Ma, Z. and Turchi, C., "Advanced Supercritical Carbon Dioxide Power Cycle Configurations for Use in Concentrating Solar Power Systems", Proceeds of the Supercritical CO2 Power Cycle Symposium, Boulder, CO, May 24-25, 2011.

7. Bryant, J., Henry, S. and Kourosh, Z., "An Analysis and Comparison of the Simple and Recompression Supercritical $\mathrm{CO}_{2}$ Cycles", Proceeds of the Supercritical CO2 Power Cycle Symposium, Boulder, CO, May 24-25, 2011.

8. Jeong, W., Jeong, Y., and Lee, J., Performance of S$\mathrm{CO}_{2}$ Brayton Cycle with Additive Gases for SFR Application", Proceeds of the Supercritical CO2 Power Cycle Symposium, Boulder, CO, May 24-25, 2011.

9. Joon, Y., Joonhan, A., Ik, L., and Addad, Y., Preliminary Results of Optimal Pressure Ratio for Superciritical $\mathrm{CO}_{2}$ Brayton Cycle coupled with Small Modular Water Cooled Reactor", Proceeds of the Supercritical CO2 Power Cycle Symposium, Boulder, CO, May 24-25, 2011.

10. Harvego, E. A. and McKellar, M. G., "Evaluation and Optimization of a Supercritical Carbon Dioxide Power Conversion Cycle for Nuclear Applications", $19^{\text {th }}$ International Conference on Nuclear Engineering, ICONE19-43824, Makuhari, Chiba, Japan, May 16-19, 2011.

11. Harvego, E. A., McKellar, M. G., O’Brien, J. E., Herring, J. S., Parametric Evaluation of Large-Scale High-Temperature Electrolysis Hydrogen Production using Different Advanced Nuclear Reactor Heat Sources, Nuclear Engineering and Design Journal, Elsevier B. V., Volume 239, Issue 9, Pages 1571-1580.

12. O'Brien, J. E., McKellar, M.G., Harvego, E. A., and Stoots, C. M., "High-temperature electrolysis for largescale hydrogen and syngas production from nuclear energy - summary of system simulation and economic analyses", International Journal of Hydrogen Energy, Elsevier B. V., Volume 35, issue 10, Pages 4808-4819, May 2010. 